GSI Journals Serie A: Advancements in Tourism, Recreation and Sports Sciences

(GSI Dergileri Seri A: Turizm, Rekreasyon ve Spor Bilimlerindeki Gelişmeler)

ATRSS 2022, 5 (1): 1-15 - Review Article/Derleme Makale - Received/Geliş T.: 14.08.2021 - Published/Kabul T.: 30.11 .2021

\title{
ULAKBİM Tarafından Taranan Ulusal Hakemli Dergilerde Yayımlanmış Gönüllü Turizm Konulu Makalelerin Bibliyometrik Analiz*
}

S. Gül GÜNEŞ, Selçuk Üniversitesi, Turizm Fakültesi, Rekreasyon Yönetimi Bölümü, gulgunes@selcuk.edu.tr, Konya, Türkiye, ORCID: 0000-0003-1107-7372

Kübra GÜNDOĞDU, Selçuk Üniversitesi, Sosyal Bilimler Enstitüsü, Turizm İşletmeciliği Anabilim Dalı, kubra.gundogdu1@outlook.com, Konya, Türkiye, ORCID: 0000-0003-3810-6858

Hasan Suat AKSU, Selçuk Üniversitesi, Turizm Fakültesi, Rekreasyon Yönetimi Bölümü, hasansuat.aksu@selcuk.edu.tr, Konya, Türkiye, ORCID: 0000-0001-8196-129X

Öz

Son yıllarda turizmde adalet duygusu ile gelişen özel ilgi turizm türlerinden gönüllü turizm, gönüllü hizmet anlayışına dayanmaktadır. Çalışma, gönüllü turizm konusunda yapılan makalelerin çeşitli kriterler doğrultusunda incelenmesi, literatüre sağlayacağı katkı ve bu alanda çalışacak olan araştırmacılara örnek olması açısından önemlidir. Bu araştırmanın amacı 20002020 yillar arasında ULAKBIM tarafindan taranan ve Fen Bilimleri ve Sosyal Bilimler alanlarında makaleler içeren ulusal hakemli dergilerde yayımlanmış "Gönüllü Turizm" konulu makalelerin bibliyometrik analizini gerçekleştirmektir. Bu amaç doğrultusunda ULAKBIM tarafindan taranan ulusal hakemli dergilerde yayımlanmış; başlık, anahtar kelime, özet ve konu içerisinde "Gönüllü Turizm" geçen makaleler incelenmiştir. Çalışma kapsamında ulaşılan 45 adet makaleye ilişkin verileri çözümlemek için içerik analizi yöntemi kullanılmıştır. Elde edilen sonuçlara göre; Türkiye'de gönüllü turizm kapsamındaki araştırmaların 2011 ve 2015 yılı arasında ivme kazandığı ve özellikle 2015 yılından itibaren artış gösterdiği, makalelerde daha çok nicel araştırma yöntemlerinin kullanıldı̆̆ı, ayrıca büyük bir çoğunluğunun Türkçe hazırlandığı belirlenmiştir. Bu noktalardan hareketle, Türkiye'de gönüllü turizm konusunda farkındalığın artmasını sağlamak için bu alanda yapılan araştırmaların nicelik ve nitelik olarak artırılması ve çeşitlendirilmesinin yanı sıra yabancı dilde yapılan çalışmaların da artırlması gerektiği ortaya konmuştur.

Anahtar Kelimeler: Gönüllü turizm, bibliyometrik analiz, ULAKBIM, makale

\section{Bibliometric Analysis of Volunteer Tourism Articles Published in National Reviewed Journals Indexed by ULAKBIM}

\begin{abstract}
Voluntary tourism, one of the alternative tourism types developed with a sense of justice in tourism recently, is based on the understanding of voluntary service. This study is important for several reasons; examining studies in line with various criteria, contributing to the literature and setting an example for researchers who will work in this field. Therefore, articles on "Volunteering Tourism" published in the national refereed journal system indexed by ULAKBIM between 2000-2020 are analyzed and keyword "Volunteer Tourism" in the title, abstract, keywords, and content were examined. Content analysis method was used to analyze the data. According to the results; In Turkey, voluntary tourism studies have gained importance between 2011-2015. Especially publications have been increased since 2015 and it was determined that the majority of the articles were prepared in Turkish and quantitative research methods used generally. Based on the results, suggestions have been made to increase and diversify the quality and quantity of research conducted in this field to raise awareness on volunteer tourism in Turkey. Besides, it has been revealed that studies in foreign languages should be increased.
\end{abstract}

Keywords: Volunteer tourism, bibliometric analysis, ULAKBIM, article

${ }^{*}$ Bu çalışma, TR Dizin etik kurul izni gerektiren çalışma grubunda yer almamaktadır. 


\section{Giriş}

Covid-19 küresel salgınının özellikle son iki yıldır yaşanan yıkıcı etkileri öncesinde turizm, yaklaşık 60 yıldır dünyanın en hızlı büyüyen ve değişen sektörlerinden biri haline gelmek için sürekli gelişme ve çeşitlilik göstermiştir (Güneş \& Dülger, 2020). Turizm sektörünün gösterdiği hızlı gelişim ile doğru orantılı olarak bu alanda gerçekleşen bilimsel araştırmaların ve dergilerin sayısında da artış görülmektedir (Böyükyılmaz \& Oktay, 2020). Üçüncü dünya ülkeleri, turizm rekabetini avantajlı bir şekilde yürütmekte ve turizmin bütün fırsatlarından yararlanmaktadırlar. Turizmin istihdam yaratma, döviz getirisi, bölgesel kalkınma gibi ekonomik etkileri, bu ülkelerin turizm arz ve talebini artırmaya yönelik çabalarını arttırmaktadır. Fakat bu katkılar genellikle yerel halka çok az ulaşmaktadır. Bunun farkında olan bazı bilim insanları yerel halkı da turizm faaliyetlerine dahil edecek ve onların da turizmin katkılarından faydalanmalarını sağlayacak alternatifler öne sürmüşlerdir (Scheyvens, 2002). Diğer yandan, çoğunlukla kitle turizminin oluşturduğu yıkıcı etkileri onarmak için geliştirilen özel ilgi turizm çeşitleri ile çevre duyarlı faaliyetlerde de artış yaşanmaya başlamıştır. Tüm bu gelişmelerle birlikte, turizmde sürdürülebilir gelişime katkı niteliğinde olan tarım turizmi, kültür turizmi, ekoturizm, toplum temelli turizm ve gönüllü turizm gibi turizm türleri ortaya çıkmıştır (Lyons \& Wearing, 2008).

Gönüllü turizm genel yapısı itibariyle gelişmiş ülkelerden az gelişmiş ülkelere gönüllü katılımcıların gönderilmesi şeklinde yapılan bir faaliyettir. Bu faaliyetlerin başarılı bir şekilde gelişmesi için gönüllü gönderen ve gönüllü kabul eden organizasyonlar arasında sağlıklı bir iletişim kurulması önemlidir (Özkul \& Birinci, 2018).

Gönüllü turizmin temelini, turistlerin seyahat ettikleri destinasyonlarda tatillerinin bir parçası olarak bölgelerin ve bölge halkının kalkındırılmasına yönelik faaliyetlere katılmaları oluşturmaktadır. Genel olarak gençlere ve gelir düzeyi yüksek kişilere hitap etmektedir (Tomazos \& Butler, 2009). Kişiler, bireysel olarak veya kurumlar aracılığı ile az gelişmiş ülkelere seyahat ederek, tatillerinin yanı sıra sosyal sorumluluk projelerinde bir kar amacı gütmeksizin çalışmaktadırlar. Bu çalışmalar, yoksulluğun giderilmesi; istihdam, eğitim ve öğretim konusunda destek sağlanması; çevrenin, tarihi ve kültürel yapıların korunması ve yenilenmesi gibi faaliyetleri kapsamaktadır. Özetle, son yıllarda turistlerin ilgi odağı haline gelen gönüllü turizm; yerelde kalkınmayı sağlayan ve turizmin olumsuz etkilerini azaltmayı amaçlayan önemli bir özel ilgi turizmi türüdür (Kurnaz, 2020).

Turizmin çok disiplinli bir alan olması, yayımlanan çeşitli konulardaki çalışmaların bibliyometrik analizlere tabi tutulmasının önünü açmaktadır. Bibliyometrik analiz; yapılan çalışmaların yöntem, teknik, yoğunluk gibi özelliklerinin incelenmesini sağlamaktadır. Bu analiz, turizm ile ilgili çalışmaların mevcut durumunun ne olduğu ve gelecekte nasıl şekilleneceği doğrultusunda rehberlik edebilir (Ercan, 2020). Ancak literatürde gönüllü turizm ile ilgili az sayıda çalışmanın tespit edilmiş olması, bu araştırmayı sinırlayan bir etmen olmuştur.

Bibliyometrik analiz çalışmalarının belirli bir zaman aralığında yapılması, ilgili bilimsel iletişim kaynağının kronolojik olarak gelişiminin belirlenmesi açısından önemlidir. Bu çalışma yöntemi birçok bilim insanının tercihinde olan bir araştırma yöntemi olmuştur (Şahin \& Acun, 2015). Bu çalışmada, Türkiye'de yayımlanan makalelerde turizmde sürdürülebilir gelişme açısından önemli bir niş pazar haline gelen gönüllü turizmin gelişimini incelemek ve bu konuda ilgili literatüre katkıda bulunmak amaçlanmıştır. Bu doğrultuda, 2000-2020 yılları arasında ULAKBİM tarafından taranan ve Fen Bilimleri ve Sosyal Bilimler alanlarında çalışmalar içeren ulusal hakemli dergilerde gönüllü turizm konusuna yer veren makalelerin bibliyometrik analizi gerçekleştirilmiştir.

\section{Gönüllülük ve Gönüllü Turizm}

Gönüllülük bireylerin hiçbir maddi kazanç ve çıkar beklentisi içine girmeden direkt kendi faaliyetleri veya kurumlar aracılığı ile üçüncü şahıslara yarar sağlamak amacı ile çevre ve toplumların yararına yapılan 
faaliyetlerde kendi arzu ve istekleriyle görev üstlenmeleri şeklinde tanımlanmaktadır (Bang \& Ross, 2009; Koşan \& Güneş, 2009). Palabıyık (2011) ise gönüllüğü; herhangi bir zorlama olmadan, beklenti içerisine girmeden, toplumun yararı düşünülerek, kurumlar aracılığı ile yapılan faaliyetler olarak açıklamaktadır. Literatürde iki tür gönüllülük kavramı vardır. Birincisi kendiliğinden gelişen plansız gönüllülük hareketi, diğeri ise kurum ve kuruluşlar tarafından planlanmış organize gönüllülük faaliyetleridir (Koşan \& Güneş, 2009).

Toplumlara ve çevreye daha az etkide bulunan ve turizm faaliyetlerini toplumlara ve çevreye yararlı kılan bir özel ilgi turizmi türü olarak gönüllü turizm, turizm faaliyetleri ile gönüllülük faaliyetlerini bir araya getirmektedir. Gönüllü turizm fedakarlık gerektirir ve bu sebeple yapı olarak diğer turizm çeşitlerinden daha farklı ele alınmaktadır (Lee \& Zhang, 2020). I. Dünya Savaşı ile birlikte gönüllülük faaliyetleri ve bu faaliyetleri organize eden sivil toplum kuruluşları belirgin bir şekilde hayata geçmiştir. Bu örgütlerden bir tanesi de İngiliz Kızılhaç kuruluşudur. Bu kuruluş 1909'da Avrupa çapında gönüllü hemşirelerle sağlık yardımlarını düzenlemiştir. İkinci Dünya Savaşı'ndan sonra 1951'de Uluslararası Avustralya Gönüllüleri kurulmuş ve gönüllülük hareketi devlet tarafından desteklenmiştir. Daha sonra 1953 yılında Uluslararası Gönüllü Hizmetleri kurulmuştur. 1961 yılında ise gönüllülük faaliyetlerini önemli bir sıçrayış yaşatan 55 ülkede projeler yapan Barış Gücü'nü kuran Başkan eski Amerika Birleşik Devletleri başkanı Kenedy olmuştur. Barış gücü iki yıllık hizmet ile 14.500 gönüllü ile işbirliği yapmıştır. 1958 yılında Birleşmiş Milletler kendi gönüllü kuruluşlarını oluşturarak kendi gönüllü turizm faaliyetlerini geliştirmiştir (Tarınç, 2020).

Gönüllü turizm faaliyetlerinin kamu ve özel sektör ortaklığı ile gerçekleştirildiği düşünüldüğünde, yerel toplumların refah seviyesini artırma çalışmalarında turistlerin görev alması ve bu süreçte kamu kurum ve kuruluşlarının Sivil Toplum Kuruluşları ile iş birliği içerisinde hareket etmesi önemlidir (Kozak \& Türktarhan, 2012).

Katılımcılar açısından gönüllü turizm, yerel toplumlarda eğitim eksikliğini giderilmesine; kadın istihdamının artırılmasına; kadın ve çocuklara yönelik istismarının önlemesi konusunda çalışmaların yapılmasına; yerel toplumların tarihi, doğal, kültürel zenginliklerinin korunmasına ve ekonomik, sosyal, fiziksel açıdan iyileştirilmesine yönelik gönüllü faaliyetlerin yürütülmesi sağlamanın yanı sıra bireylerin kendi iç huzurunu yaşayabilecekleri ve bu süreçte turizm faaliyetlerine katılarak tatillerini gerçekleştirebilecekleri bir turizm çeşididir (Ar \& Uğuz, 2014; Stoddart \& Rogerson, 2004).

Gönüllü turizme katılanların demografik yapısı incelendiğinde, daha çok ekonomik durumu iyi olan ve esnek seyahat şartlarına sahip kişiler ile genç bireylerden oluştukları görülmektedir. Gezgin olarak da nitelendirilen bu kişiler için, motivasyon oluşturacak aktivitelere katılmak ve farklı deneyimler yaşamak önemlidir (Scheyvens, 2002). Katılımcıların bazıları kariyer planlaması içeresinde gönüllü faaliyetlere katılım gösterseler de daha çok geri kalmış ülke ve bölgelerin geliştirilmesi, ekonomik kalkınması, tehdit altında olan bitki ve hayvan türleri ile kültürel, tarihi ve doğal unsurların korunması amacı ile gerçekleşmektedir. Bu nedenler doğrultusunda gönüllü turizm faaliyetleri için genel olarak tercih edilen bölgeler; Afrika, Asya ve Pasifik olmaktadır (Wilkinson, vd., 2014).

Gönüllü turizm katılımcılarının deneyimleri sonrası alışkanlık ve tutumlarında değişikler yaşandığı ve bu durumun hayatlarına da etki ettiği savunulmaktadır. Örneğin, gönüllü faaliyet sonrası katılımcıların hayata dair değerlendirmelerinde maddi varlıklara yönelişten çok maneviyata önem verme şeklinde bir değişim gözlemlenebilmektedir (Zahra \& Mcintosh, 2007). Bu nedenle, gönüllü turizmin sadece yerel toplumlar üzerinde değil katılımcı turistler üzerinde de önemli etkiler oluşturduğunu söylemek mümkündür (Palacios, 2010).

Araştırmalar son yıllarda turizmin deneyimsel yapısının daha çok ortaya konduğunu, toplumsal ve doğal değişime odaklandığını ortaya koymaktadır. Bununla birlikte seyahatlerin de turizmin olumlu etkilerine odaklanması ve yerel toplumların refahına yönelik ilgi özel ilgi turizmi kavramının önem kazanması söz konusu olmuştur. Özel ilgi turizmi kapsamında ele alınabilecek gönüllü turizm de amaç olarak 
sürdürülebilir gelişmeyi destekleyen, toplumların ve bölgelerin gelişimine odaklanan bir turizm çeşidi olarak nitelendirilmektedir. Özellikle son y1llarda gelişimi ivme kazanan bu turizm türüne yönelik araştırma çalışmalarının sayısında da artış yaşanmıştır (Coghlan \& Fennell, 2009; Yılmaz, 2019; Leong vd., 2020; Romero vd., 2021).

Günümüzde tüm dünyada gönüllü turizm faaliyetlerini düzenleyen çok sayıda kuruluş bulunmaktadır. Bu kuruluşların bazıları çalışmalarını gençlik turizmi ile birlikte yürütmektedir. Kanada'da kurulan "Canada World Youth"; yaşam şartlarının iyileştirilmesi ve kadın haklarının korunması konusunda Avustralya'da faaliyet göstermektedir. Benzer şekilde, "Inter Cultural Youth Exchange”, "International Cultural Youth Exchange", "Volunteer Action for Peace", "World Youth International" ve "Religous Youth Services" gibi temel amacı gönüllülük ve gençlik turizmi olan kuruluşlar; insan hakları ve kadın haklarının korunması, salgın hastalıklar hakkında bilgilendirme, sokak çocuklarının topluma kazandırılması, ilkokul inşaatı ve evsizlere barınma yerlerinin yapılması şeklinde faaliyetler yürütmektedirler. Bu organizasyonların gönüllü seyahat düzenledikleri hedef destinasyonlar arasında; Kosta Rika, Kolombiya, Panama, Tanzanya, Ekvator, Hindistan gibi ülkeler yer almaktadır (Kozak \& Türktarhan, 2012).

\section{Bibliyometrik Analiz}

Bibliyometrik kelimesi biblio ve metric kelimelerinin birleşiminden oluşmakta ve köken olarak eski Yunancada (grek) kitap anlamına gelen biblio kelimesinden gelmektedir. Bibliyometrik bilimsel yazıların, kitapların istatistiksel ve matematiksel açıdan incelenmesi ve değerlendirilmesi için kullanılan bir yöntemdir. Bu yöntem ile yazarların, dergilerin, kurumların değerlendirilmesi yapılabilir (Bozok, Kılıç \& Özdemir, 2017). Fahimnia vd. (2015)'e göre bibliyometrik analiz, kitap, dergi, makale vb. bilimsel araştırmaların istatiksel ve matematiksel analizleri ile belirli parametreler doğrultusunda incelenmesidir. Bibliyometrik analiz yöntemi son yıllarda adını çokça duyuran ve gündemde olan bir analiz yöntemi olmakla birlikte aslında ilk bibliyometrik analiz yönteminin kullanımı 1920'lerden öncesine dayanmaktadır (Bozok vd., 2017). Polat vd. (2019)'a göre; bibliyometri alanından yapılan ilk çalışma 1917 yılında Cole ve Eales tarafından anatomi alanında yapılmış çalışmaların analizleridir.

Kitaplar, dergiler ve diğer bilimsel iletişim araçlarının bibliyometrik analizinin yapılması bu çalışmaların karşılaştııılmasında, hangi çalışmaların daha çok kullanılıp yarar sağladığının belirlenmesinde ve etkin yazarların, çalışmaların ve dergilerin belirlenmesinde önemli rol oynamaktadır (Ulu \& Akdağ, 2015). Bibliyometrik analiz tanımlayıcı ve değerlendirici olarak iki başlık altında incelenebilir. Tanımlayıcı bibliyometrik analiz çalışması makalelerin genel hatlarını tanımlar nitelikte iken değerlendirici bibliyometrik analiz çalışması makalelerin atıf sayıları ile ilgili verileri derleyerek daha sonra yapılan çalışmaları nasıl ve ne kadar etkilediğiyle ilgilenmektedir (Demirbulat \& Dinç, 2017). Bibliyometrik çalışmalar sonucunda bilimsel araştırmalara ve bilimsel iletişime ilişkin belirli bulgulara ulaşmak mümkündür. Elde edilen veriler, dergilere, kitaplara ve ülkelerin bilimsel evrenine yön verebilecek düzeyde olabilir (Karagöz \& Kozak, 2014).

\section{Yöntem}

Bu araştırmada, gönüllü turizm konusunda Türkiye'de yayımlanan makalelerin içerik analizi yöntemlerinden biri olan bibliyometrik analiz yöntemi ile incelenmesi sayesinde; konuya ilişkin alan yazın gelişiminin ve söz konusu makalelerin özelliklerinin ortaya konması amaçlanmıştır.

Küresel anlamda "Birleşmiş Milletler" tarafından 1972 yılında başlatılan uluslararası çevrecilik hareketleri, 1987 yılında yayımlanan "Ortak Geleceğimiz" adlı rapor ile geçtiğimiz yüzyıla damgasını vurabilmiştir. Raporun en çarpıcı noktası ise "Sürdürülebilir Kalkınma" kavramının tanıtılmış olmasıdır. Küresel anlamda çevrecilik hareketlerinin hız kazanmasıyla birlikte 1992 yılında Rio'da “Birleşmiş 


\section{5 (1): $1-15$}

Milletler Çevre ve Kalkınma Konferansı" düzenlenmiş ve çevre üzerindeki baskılar bir kez daha uluslararası alanda tartışılmıştır. Süreç içinde kalkınmanın çevreyi göz ardı etmeden gerçekleşmesi konusu giderek önem kazanmış ve Milenyum çağı ile birlikte çevre duyarlı tüketici gruplarının arttığ gözlemlenmiştir. Diğer yandan, bu doğrultuda oluşan talebi karşılamak üzere çevre dostu turistik tesisler de yaygınlaşmaya başlamıştır (Hunter \& Green, 1995; Nyberg vd., 1996; Wall, 1997; Tosun, 2001). Tüm bu gelişmelere paralel olarak, turizmde çevreyle uyumlu sürdürülebilir gelişme açısından önemli bir niş pazar olan gönüllü turizm de özellikle son 20 yıldır bilimsel çalışmalarda ele alınan önemli konular arasında yer aldığından; bu araştırmaya dahil edilen makaleler 2000-2020 yıllarını kapsamaktadır.

Çalışmada bu kapsamda, ULAKBİM (Ulusal Akademik A ğ ve Bilgi Merkezi) tarafından taranan ulusal hakemli dergilerde 2000-2020 yılları arasında yayımlanmış makaleler incelenmiştir. Çalışma kapsamında, arama kriteri olarak tüm alanlarda (Fen Bilimleri ve Sosyal Bilimler alanlarında) başlık, anahtar kelime, özet ve konu içerisinde "Gönüllü Turizm” geçen makaleler incelenmiştir.

Gönüllü turizm kavramının literatürde yeni gelişen bir kavram olması ve çalışma kapsamında incelenen makalelerin 2000-2020 yılları arasında yayımlanmış olması çalışmanın sınırlılıklarını oluşturmaktadır. Bu çalışma, konu kapsamında belirlenen 45 makalenin bibliyometrik yapılarını tespit etmeyi ve süreç içerisindeki gelişimlerini ortaya koymayı amaçlayan nicel bir araştırmadır. Araştırmada elde edilen veriler Jamovi 1.6.15 paket programına aktarılarak yüzde ve frekansları alınmıştır. Makalelerin incelemesi ile şu sorulara cevap aranmıştır:

- Makaleler hangi yıllar arasında yayımlanmıştır?

- Makalelerin çıkış noktası nedir?

- Makalelerde kullanılan anahtar kelime yoğunluğu nedir?

- Makaleler kaç yazarla yazılmıştır?

- Makaleler en fazla hangi dilde yayımlanmıştır?

- Makalelerin araştırma yöntemine (nitel, nicel, karma) göre dağılımları nasıldır?

- Makalelerde hangi veri toplama tekniği daha fazla kullanılmıştır?

- Makalelerde araştırılan illerin dağılımı nedir?

- Makalelerde en çok kullanılan veri kaynağı nelerdir?

- Makalelerin konu dağılımı nedir?

\section{Bulgular}

ULAKBİM tarafından taranan ulusal hakemli dergilerde 2000-2020 yılları arasında gönüllü turizm konusunda yayımlanmış makaleler incelendiğinde, çalışmaların toplamda 31 dergi çerçevesinde gerçekleştirildiği ve bu dergilerin daha çok turizm kapsamında çalışmalara yer verdikleri görülmektedir.

Tablo 1. Makalelerin Yayımlandığı Dergiler

\begin{tabular}{|c|c|c|c|}
\hline Sira No & Dergi İsimleri & Frekans & Oran $(\%)$ \\
\hline 1 & Anatolia: Turizm Araştırmaları Dergisi & 6 & $13 \%$ \\
\hline 2 & Journal of Tourism and Gastronomy Studies & 5 & $11 \%$ \\
\hline 3 & Balıkesir Üniversitesi Sosyal Bilimler Enstitüsü Dergisi & 2 & $4 \%$ \\
\hline 4 & Journal of Language and Linguistic Studies & 2 & $4 \%$ \\
\hline 5 & Öneri Dergisi & 2 & $4 \%$ \\
\hline 6 & Selçuk Üniversitesi Sosyal Bilimler Enstitüsü Dergisi & 2 & $4 \%$ \\
\hline
\end{tabular}


Güneş, S.G., Gündoğdu K. \& Aksu, H. S. (2022). Bibliometric Analysis of Volunteer Tourism Articles Published in National Reviewed Journals Indexed by ULAKBIM. GSI Journals Serie A: Advancements in Tourism, Recreation and Sports Sciences (ATRSS), 5 (1): $1-15$

\begin{tabular}{|c|c|c|c|}
\hline 7 & Seyahat ve Otel İşletmeciliği Dergisi & 2 & $4 \%$ \\
\hline 8 & Atatürk Araştırma Merkezi Dergisi & 1 & $2 \%$ \\
\hline 9 & Çağdaş Türkiye Tarihi Araştırmaları Dergisi & 1 & $2 \%$ \\
\hline 10 & Çukurova Üniversitesi Sosyal Bilimler Enstitüsü Dergisi & 1 & $2 \%$ \\
\hline 11 & Dokuz Eylül Üniversitesi Denizcilik Fakültesi Dergisi & 1 & $2 \%$ \\
\hline 12 & Finans Politik ve Ekonomik Yorumlar Dergisi & 1 & $2 \%$ \\
\hline 13 & Folklor/Edebiyat & 1 & $2 \%$ \\
\hline 14 & IIB International Refereed Academic Social Sciences Journal & 1 & $2 \%$ \\
\hline 15 & İ M K B Dergisi & 1 & $2 \%$ \\
\hline 16 & İleti-ş-im Dergisi & 1 & $2 \%$ \\
\hline 17 & İnsan ve Toplum Bilimleri Araştırmaları Dergisi & 1 & $2 \%$ \\
\hline 18 & İşletme Araştırmaları Dergisi & 1 & $2 \%$ \\
\hline 19 & Journal of Education and Future & 1 & $2 \%$ \\
\hline 20 & Journal of Yasar University & 1 & $2 \%$ \\
\hline 21 & Karamanoğlu Mehmetbey Üniversitesi Sosyal ve Ekonomik Araştırmalar Dergisi & 1 & $2 \%$ \\
\hline 22 & Manas Journal of Social Studies & 1 & $2 \%$ \\
\hline 23 & Moment Dergi & 1 & $2 \%$ \\
\hline 24 & Nevşehir Hacı Bektaş Veli Üniversitesi SBE Dergisi & 1 & $2 \%$ \\
\hline 25 & Spormetre Beden Eğitimi ve Spor Bilimleri Dergisi & 1 & $2 \%$ \\
\hline 26 & Tarih Araştırmaları Dergisi & 1 & $2 \%$ \\
\hline 27 & Tarih Okulu Dergisi & 1 & $2 \%$ \\
\hline 28 & Tesam Akademi & 1 & $2 \%$ \\
\hline 29 & Turizm Akademik Dergisi & 1 & $2 \%$ \\
\hline 30 & Yükseköğretim Dergisi & 1 & $2 \%$ \\
\hline \multirow[t]{2}{*}{31} & Yüzüncü Y1l Üniversitesi Sosyal Bilimler Enstitüsü Dergisi & 1 & $2 \%$ \\
\hline & & 45 & $0 \%$ \\
\hline
\end{tabular}

Tablo 1. incelendiğinde dergilerin çoğunlukla üniversite dergileri olduğu sonucuna varılmıştır. Gönüllü turizm alanında yapılan araştırmaların yayımlandıkları dergiler incelendiğinde en fazla oranla 45 makalenin altısının (\%13) turizm araştırmaları dergisi olan "Anatolia: Turizm Araştırmaları Dergisi" ve beşinin (\%11) “Journal Tourism and Gastronomy Studies”' 'dergisinde yayımlandı̆̆ belirlenmiştir. 
Güneş, S.G., Gündoğdu K. \& Aksu, H. S. (2022). Bibliometric Analysis of Volunteer Tourism Articles Published in National Reviewed Journals Indexed by ULAKBIM. GSI Journals Serie A: Advancements in Tourism, Recreation and Sports Sciences (ATRSS), 5 (1): $1-15$

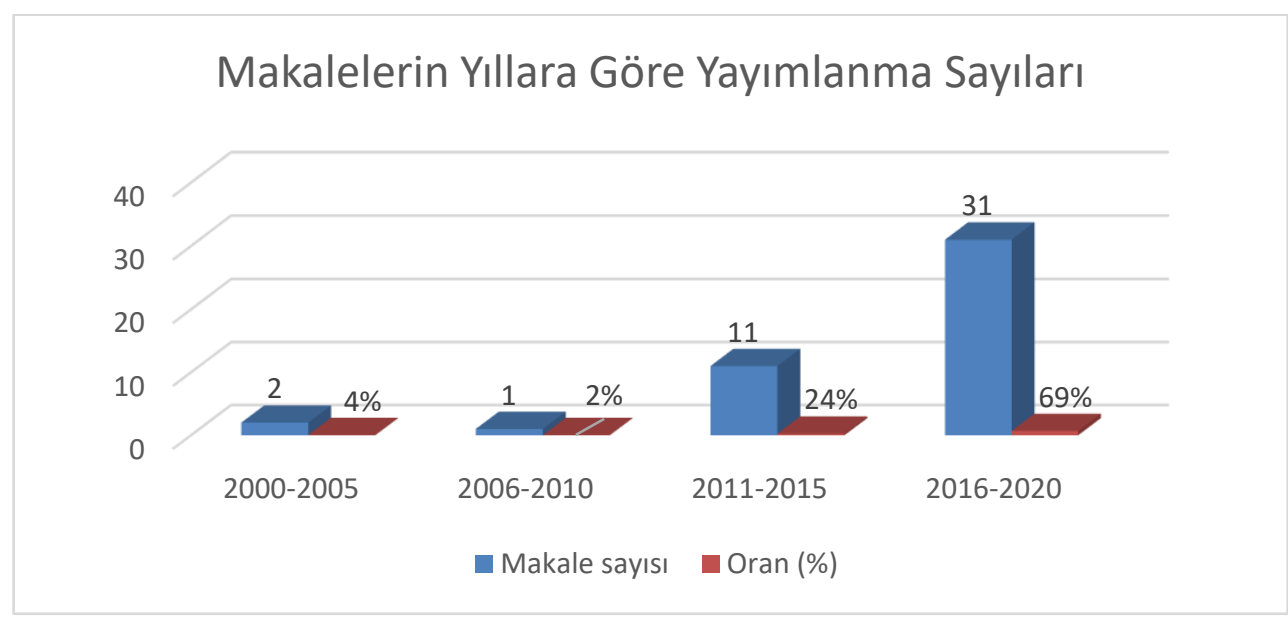

Şekil 1. Makalelerin Yıllara Göre Yayımlanma Sayıları

Şekil 1 incelendiğinde konu ile ilgili yayımların 2011 ve 2015 yılı arasında ivme kazandığı ve gönüllü turizm alanında yapılan çalışmaların sayısında 2015 yılından sonra önemli artış yaşandığı görülmektedir.

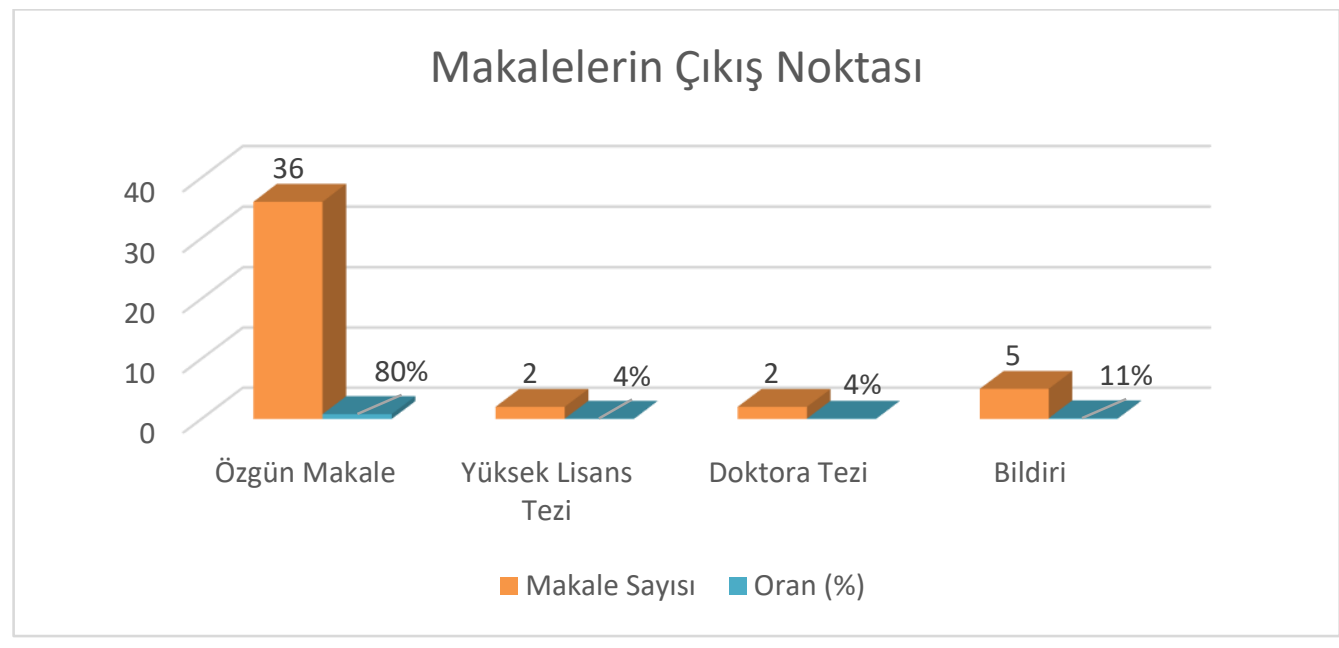

Şekil 2. Makalelerin Çıkış Noktası

Şekil 2 incelendiğinde makalelerin \%80'inin özgün makale olarak ortaya konduğu görülmektedir. Ayrıca makalelerin \%11'i bildiriden oluşturulmakla birlikte, \%4 oranında yüksek lisans tezinden ve \%4 oranında da doktora tezinden geliştirildiği belirlenmiştir.

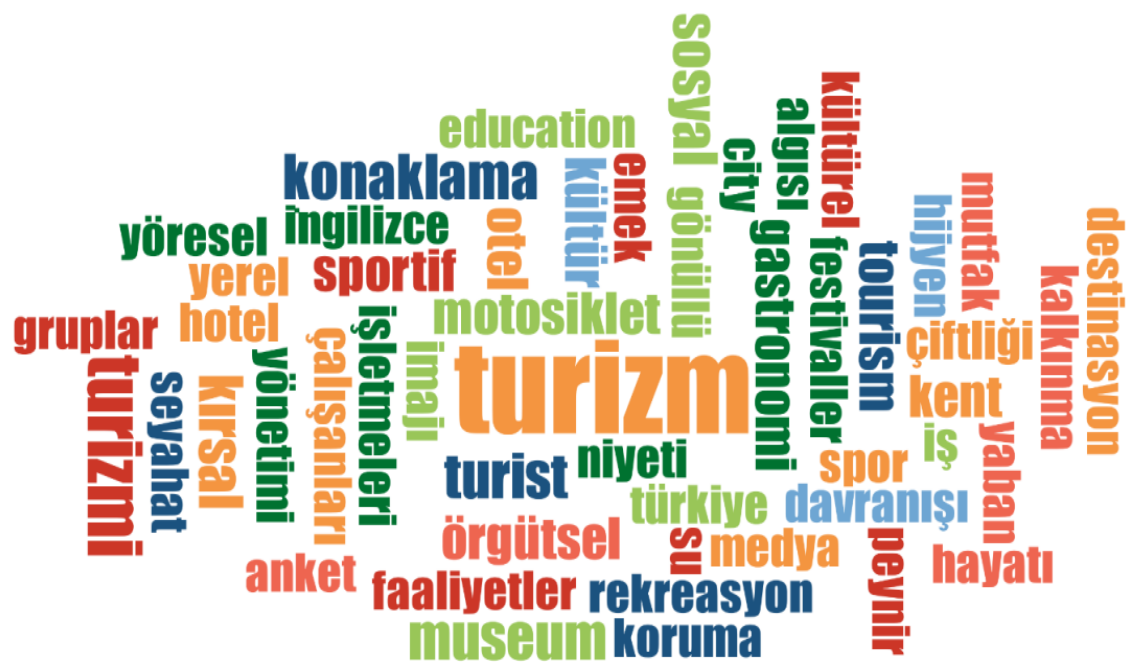

Şekil 3. Kelime Bulutu - Anahtar Kelimeler 
Toplam 321 anahtar kelime içerisinden "turizm" kelimesinin \%9,25 oranla ilk sirada yer aldı̆̆ görülmektedir. Daha sonra sirasıyla \%2 ile "turist", \%2 ile "konaklama", \%2 ile "gastronomi" ve \%2 ile "rekreasyon" kavramları anahtar kelimeler olarak seçilmiştir.

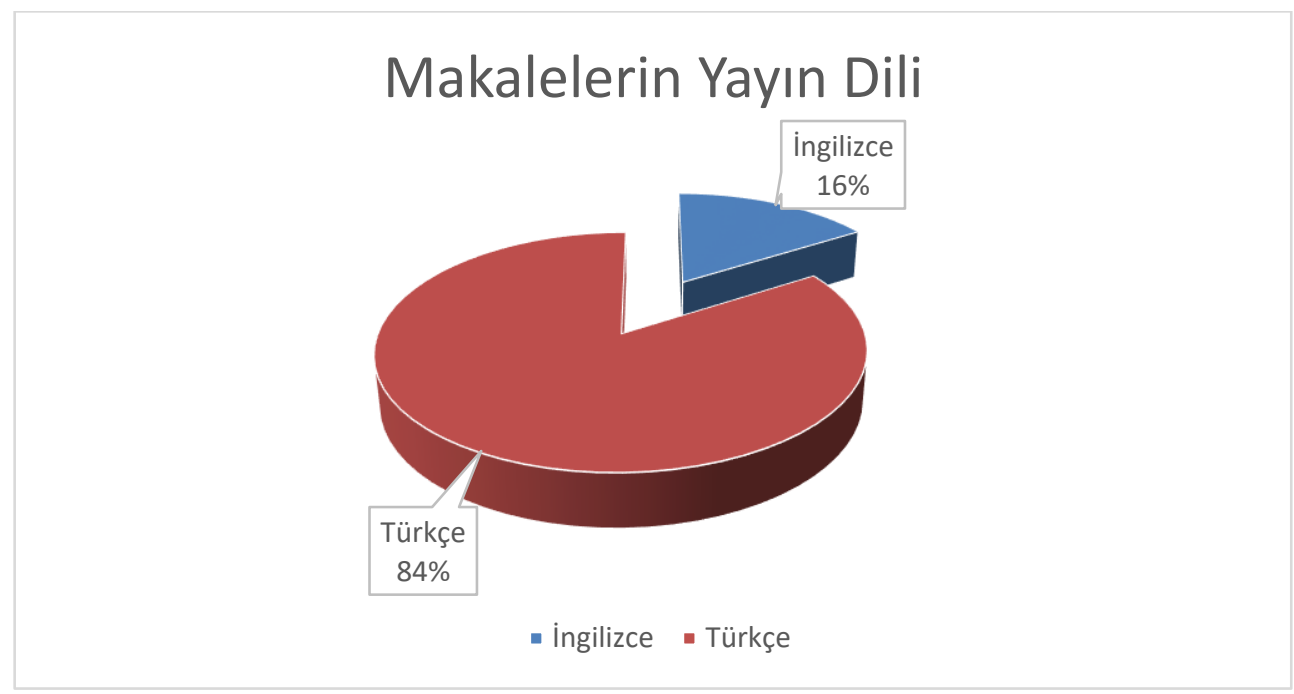

Şekil 4. Makalelerin Yayın Dili

Şekil 4'de makalelerde kullanılan yayın dilinin \%84 gibi yüksek bir oranla Türkçe olduğu tespit edilmiştir.

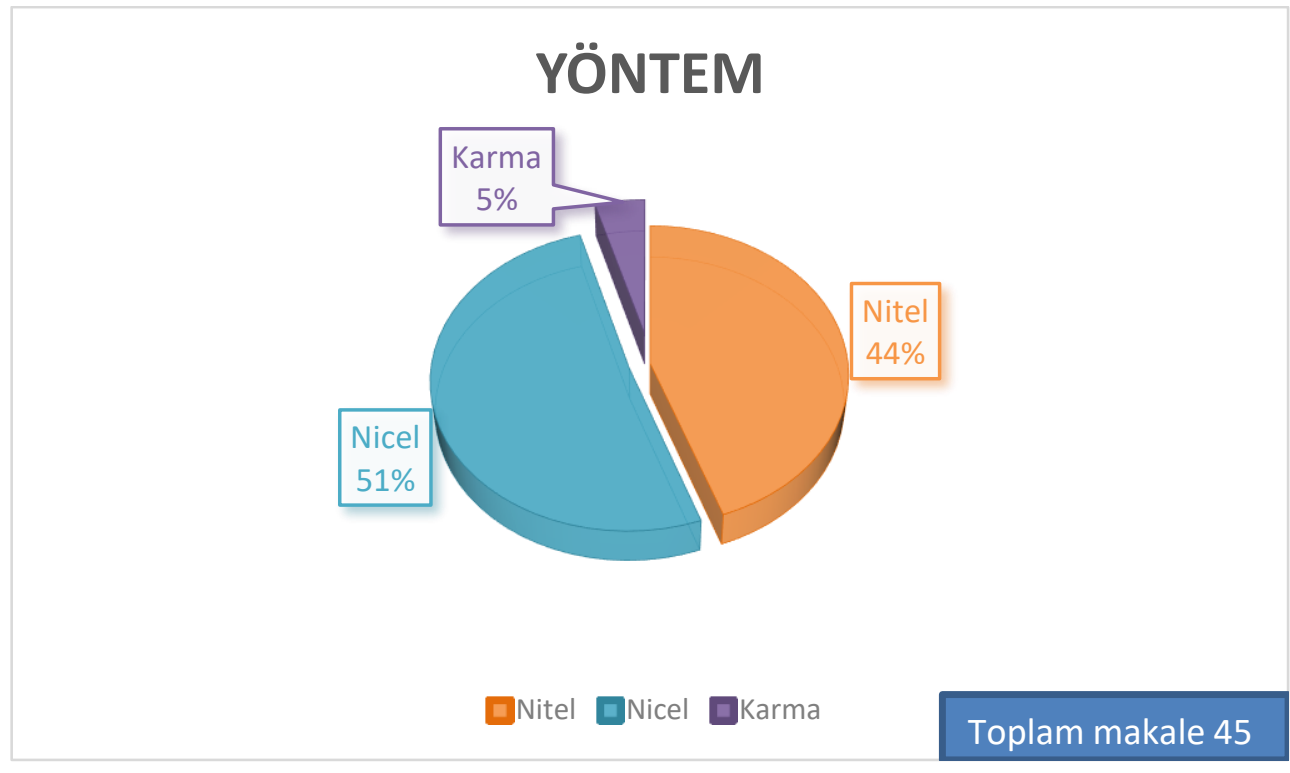

Şekil 5. Makalelerde Kullanılan Araştırma Yöntemi

Şekil 5'de incelenen makalelerin en çok nicel araştırma yöntemi olarak ortaya konulduğu görülmektedir. Makalelerin \%51'i nicel yöntemle oluşturulurken, \%44'ünde nitel yöntem kullanılmıştır. Yayımlarda en az kullanılan yöntem ise \%5 oran ile karma yöntemdir. 
Güneş, S.G., Gündoğdu K. \& Aksu, H. S. (2022). Bibliometric Analysis of Volunteer Tourism Articles Published in National Reviewed Journals Indexed by ULAKBIM. GSI Journals Serie A: Advancements in Tourism, Recreation and Sports Sciences (ATRSS), $5(1): 1-15$

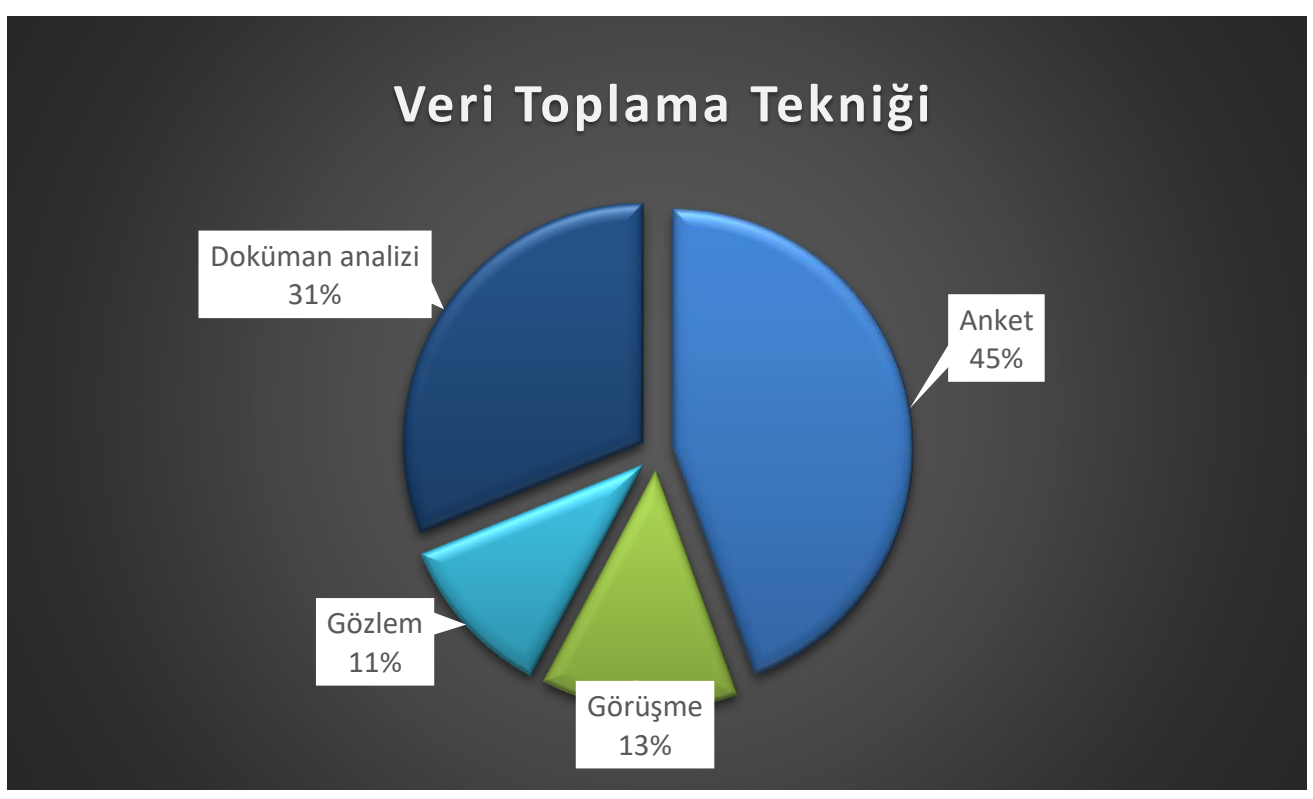

Şekil 6. Makalelerde Kullanılan Veri Toplama Tekniği

Şekil 6'da görüldügü gibi en çok tercih edilen veri toplama yönteminin anket (\%45) ve doküman analizi (\%31) olduğu tespit edilmiştir. Daha az tercih edilen veri toplama yöntemlerinin ise görüşme (\%13) ve gözlem (\%11) olduğu görülmektedir.

Tablo 2. Makalelerin Konu Dağılımı

\begin{tabular}{|c|c|c|c|}
\hline Sayı & Konular & Frekans & Yüzde \\
\hline 1 & Gönüllülük ve Rekreasyon & 4 & $9 \%$ \\
\hline 2 & Çalışan Motivasyonu & 4 & $9 \%$ \\
\hline 3 & Oryantasyon Süreci & 3 & $7 \%$ \\
\hline 4 & Destinasyon İmajı & 3 & $7 \%$ \\
\hline 5 & Gönüllülük ve Turizm & 2 & $4 \%$ \\
\hline 6 & Gönüllülük Nedenleri & 2 & $4 \%$ \\
\hline 7 & Tanıtım Faaliyetleri & 2 & $4 \%$ \\
\hline 8 & Örnek Olay İncelemesi & 2 & $4 \%$ \\
\hline 9 & Seyahat & 2 & $4 \%$ \\
\hline 10 & Gönüllülük ve Kalkınma & 2 & $4 \%$ \\
\hline 11 & Zaman Yönetimi & 2 & $4 \%$ \\
\hline 12 & Rekreasyonel Gruplar & 2 & $4 \%$ \\
\hline 13 & Öğrenci Motivasyonları & 2 & $4 \%$ \\
\hline 14 & Rekreasyonel Eğilimler & 2 & $4 \%$ \\
\hline 15 & Müşteri potansiyeli & 2 & $4 \%$ \\
\hline 16 & Gastronomi ve Tercih Nedenleri & 2 & $4 \%$ \\
\hline
\end{tabular}


Güneş, S.G., Gündoğdu K. \& Aksu, H. S. (2022). Bibliometric Analysis of Volunteer Tourism Articles Published in National Reviewed Journals Indexed by ULAKBIM. GSI Journals Serie A: Advancements in Tourism, Recreation and Sports Sciences (ATRSS), $5(1): 1-15$

\begin{tabular}{clcc}
\hline 17 & Gönüllülük ve Kültür & 2 & $4 \%$ \\
\hline 18 & Gönüllülük ve STK'lar & 1 & 1 \\
\hline 19 & Göçmenler & 1 & $2 \%$ \\
\hline 20 & Gönüllülük ve Kuşaklar & 1 & $2 \%$ \\
\hline 21 & Ölçek Geliştirme & 1 & $2 \%$ \\
\hline 22 & Sosyal Sorumluluk Projeleri & Toplam & 45 \\
\hline
\end{tabular}

Tablo 2' de görüldüğü üzere, araştırmacıların en fazla yöneldiği konuların "Gönüllülük ve Rekreasyon" (\%9) ve “Çalışan motivasyonu" (\%9) olduğu görülmektedir. Diğer yandan “Gönüllülük ve STK'lar" (\%1), "Gönüllülük ve Kuşaklar" (\%1), "Göçmenler" ve "Sosyal Sorumluluk Projeleri" (\%1) kapsamindaki konular ise en az çalışılan alanlardır.

Tablo 3. Makalelerin Araştırma Sahası

\begin{tabular}{|c|c|c|c|}
\hline & & Makale Sayısı & Oran (\%) \\
\hline \multirow{16}{*}{ Şehirler } & Adana & 1 & $2 \%$ \\
\hline & Ankara & 3 & $7 \%$ \\
\hline & Antalya & 4 & $9 \%$ \\
\hline & Aydın & 1 & $2 \%$ \\
\hline & Balıkesir & 1 & $2 \%$ \\
\hline & Erzurum & 1 & $2 \%$ \\
\hline & İstanbul & 2 & $4 \%$ \\
\hline & İzmir & 2 & $4 \%$ \\
\hline & Isparta & 1 & $2 \%$ \\
\hline & Konya & 1 & $2 \%$ \\
\hline & Nevşehir & 1 & $2 \%$ \\
\hline & Rize & 1 & $2 \%$ \\
\hline & Uşak & 1 & $2 \%$ \\
\hline & Türkiye Geneli & 24 & $53 \%$ \\
\hline & Diğer & 1 & $2 \%$ \\
\hline & Toplam & 45 & 100 \\
\hline
\end{tabular}

Tablo 3' de araştırmanın yapıldı̆̆ 1 saha verileri sunulmuştur. Araştırmalarda kullanılan ve en fazla orana sahip olan saha \%53 ile Türkiye geneli olmuştur. İkinci sırada \%9 oran ile Antalya, üçüncü sırada \%7 ile Ankara ve dördüncü sırada \%4 oranı ile İstanbul ve İzmir gelmektedir. Adana, Aydın, Balıkesir, Erzurum, 
Güneş, S.G., Gündoğdu K. \& Aksu, H. S. (2022). Bibliometric Analysis of Volunteer Tourism Articles Published in National Reviewed Journals Indexed by ULAKBIM. GSI Journals Serie A: Advancements in Tourism, Recreation and Sports Sciences (ATRSS),

\section{5 (1): $1-15$}

Isparta, Konya, Nevşehir, Rize, Uşak ve diğer olarak belirlenen araştırma sahalarının makalelerde kullanım oranları ise $\% 2$ olarak tespit edilmiştir.

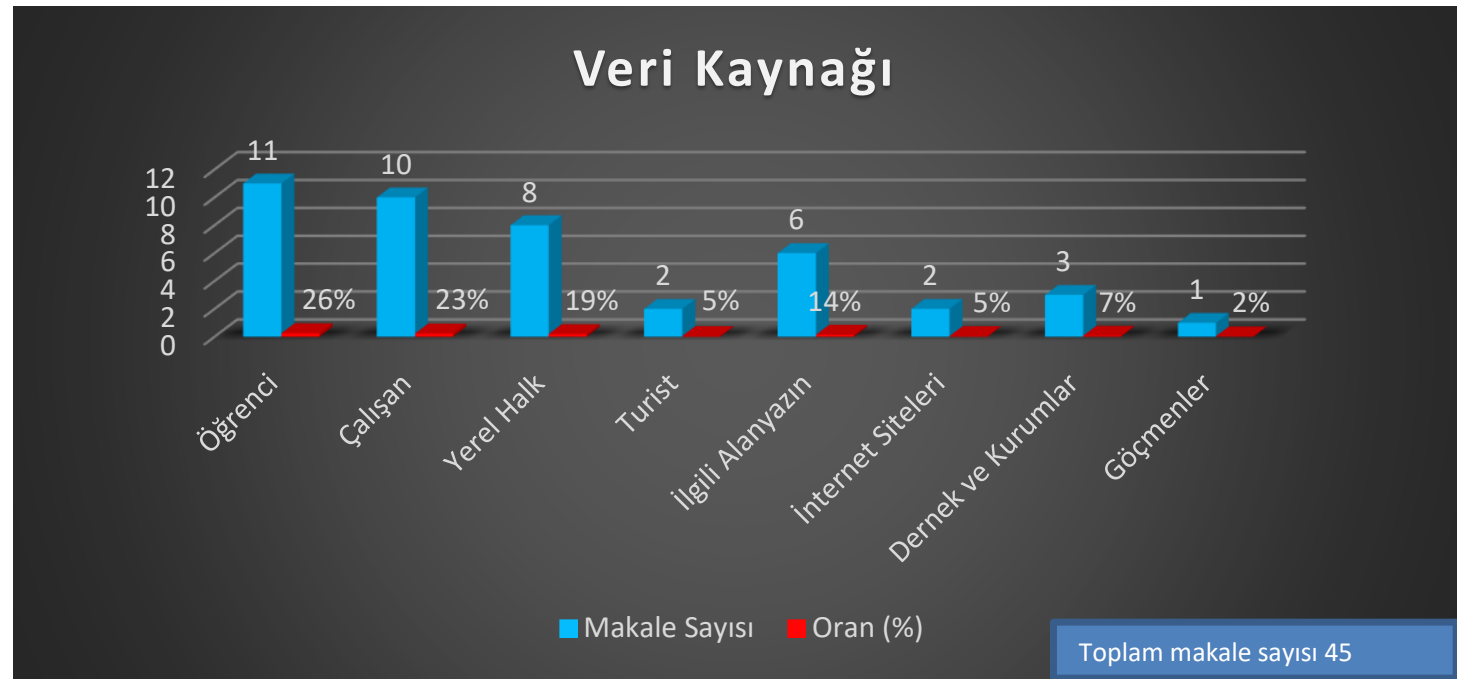

Şekil 7. Makalelerde Kullanılan Veri Kaynakları

Şekil 7'de görüldüğü üzere en fazla kullanılan veri kaynağ1 \%26 oran ile öğrenciler ve \%23 ile çalışanlar olmuştur. Diğer veri kaynakları ise sırası ile \%19 oran ile yerel halk, \%14 oran ile ilgili alan yazın, \%7 ile dernek ve kurumlar, \%5 ile internet siteleridir. En az kullanılan veri kaynağ 1 ise \%2 oran ile göçmenler olmuştur.

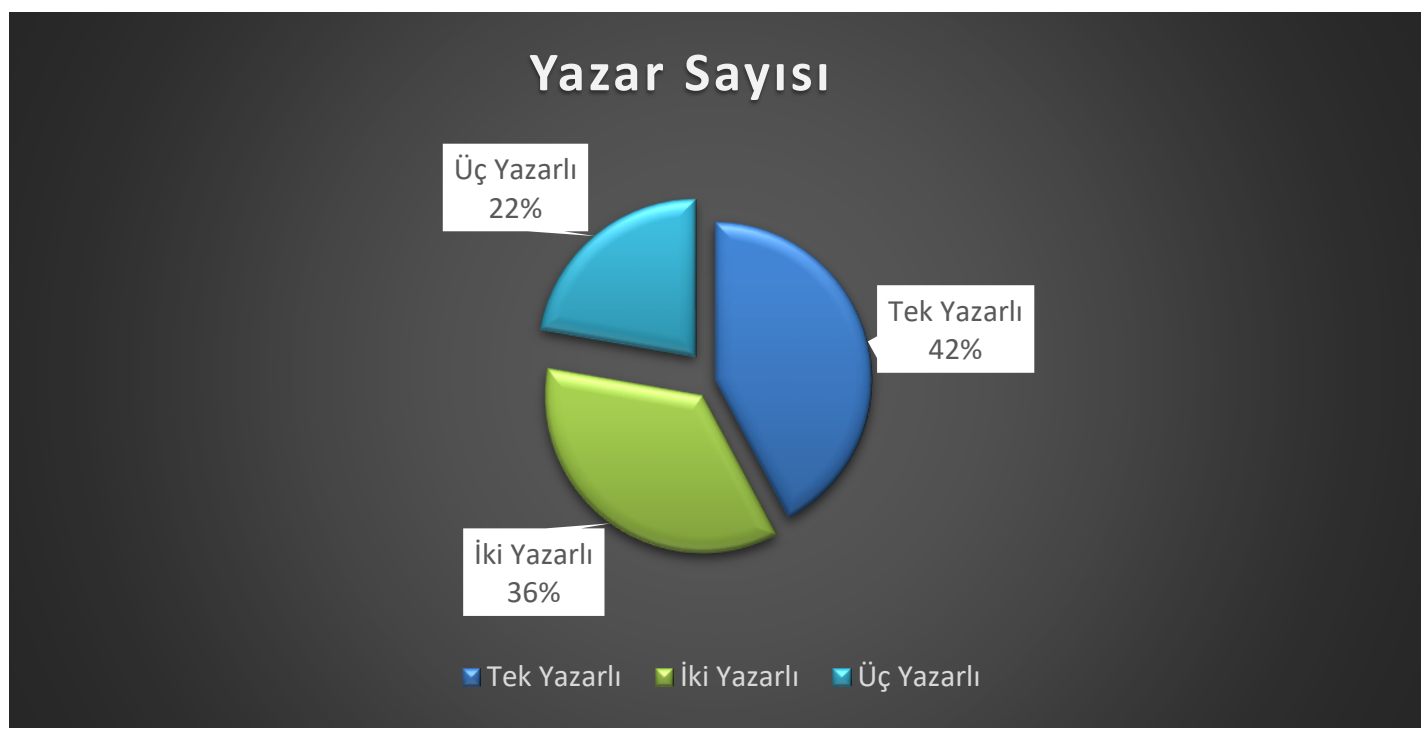

Şekil 8. Makalelerin Yazar Sayıları

Şekil 8' de makalelerin yazar sayıları oranı ortaya konulmuştur. Bu verilere göre makalelerin \%42 oranı ile daha çok tek yazarlı olduğu görülmektedir. Diğer yandan makalelerin \%36'sı iki yazarlı, \%22'si ise üç yazarlidir.

\section{Sonuç ve Öneriler}

Gönüllü turizm son yıllarda gelişen ve dünya genelinde ivme kazanmaya başlamış bir turizm türüdür. Yapılan araştırmalara göre; ülkelerin ve bölgelerin kalkınmasında önemli bir role sahip olup, özellikle az gelişmiş ülkelerin turizmde rekabet gücünü artırmaktadır. Bu nedenle, Türkiye'de gönüllü turizm konusunda yapılan araştırmaların durumuna ilişkin bir değerlendirmenin yapılması oldukça önemlidir. Çalışmada bu doğrultuda, ULAKBİM veri tabanında yer alan dergilerde 2000-2020 yılları arasında 
yayımlanan gönüllü turizm ile ilgili makalelerin incelenmesi amaçlanmıştır. Değerlendirme sonucunda toplam 45 adet makaleye ulaşılmış ve bibliyometrik analiz gerçekleştirilmiştir.

İnceleme sonucunda, gönüllü turizm alanındaki makalelerin turizm dergilerinde yayımlanma oranı \%26 olarak belirlenmiştir. Turizm alanındaki dergiler içinde ise yayın oranı en fazla olan iki dergi, “Anatolia Turizm Araştırmaları Dergisi" ve "Journal of Tourism and Gastronomy Studies" olarak tespit edilmiştir. Dolayısıyla turizm alanındaki farklı dergilerde gönüllü turizm konusunda yayımlanan çalışmaların sayı, kapsam ve niteliklerinin artırılması, bu konunun önemine yönelik farkındalığın artmasını sağlayacaktır.

ULAKBİM tarafından taranan ulusal hakemli dergilerde gönüllü turizm alanında yapılan çalışmalar, 2011 yılından itibaren artış göstermektedir. Bu da gönüllü turizm konusundaki farkındalığının daha çok son on yılda artmakta olduğunu ortaya koymaktadır. Özellikle COVID-19 küresel salgını sonrasında, sorumlu ve sürdürülebilir turizm anlayışının en rahat uygulanabileceği gönüllü turizm benzeri turizm türlerine olan ilgi de artacağından bu konuda yapılacak bilimsel çalışmaların uzun yıllar ilgi görmeye devam etmesi söz konusu olacaktır.

Araştırma sahası olarak en fazla (\%53) Türkiye geneli ele alınmış ve veri kaynağı olarak en fazla öğrenciler (\%26) ile çalışanlar (\%23) tercih edilmiştir. Veri kaynağı olarak en fazla öğrencilerin kullanılmasında, bu örneklem grubuna araştırmacıların kısmi olarak daha kolay ulaşmasının etkili olduğu düşünülmektedir. İleride yapılacak olan çalışmalarda turistler ve yerel halk gibi farklı veri kaynaklarının kullanılması sayesinde alanda yayımların çeşitlendirilmesi ve farklı hedef kitlelerin konuya ilişkin görüşlerinin değerlendirilebilmesi mümkün olabilecektir. Araştırma sahasının büyük çoğunlukla Türkiye genelinden oluşması literatüre zengin bir kaynak birikimi sunmaktadır. Diğer yandan, gelecekte yapılması planlanan çalışmaların bölgesel anlamda ele alınması ve yurtdışı örneklerle kıyaslamalı çalışılması sayesinde, konuya ilişkin deneyim paylaşımlarının ve örnek çalışmaların çeşitlendirilmesi sağlanabilir. Makalelerin neredeyse tümü (\%80) özgün çalışmalardan oluşmaktadır. Bu sonucun ise alanın kısmi olarak yeni olmasından kaynaklandığı düşünülmektedir.

Yayımlanan çalışmalarda en fazla (\%51) nicel araştırma yöntemi ve veri toplama tekniği olarak da en çok anket (\%44) tercih edilmiştir. Bundan sonra yapılacak araştırmalarda, nitel araştırma yönteminin ve gözlem-mülakat-doküman analizi gibi farklı veri toplama tekniklerinin de kullanımı ile çeşitliliğin sağlanması önemli olacaktır. Makalelerin çoğu (\%42) tek yazarlı olarak yayımlanmıştır. İleride ortak yazarlı ve mümkünse çok disiplinli araştırmaların da yapılması sayesinde gönüllü turizmin farklı yönlerinin ortaya konabilmesi ve farklı meslek disiplinlerinin perspektifinden yorumlanabilmesi mümkün olacaktır.

Araştırma konularından elde edilen sonuca göre; en fazla çalışmanın “Gönüllülük ve Rekreasyon” (\%9) ve "Çalışan Motivasyonu" (\%9), en az çalışma alanına sahip konuların ise “Gönüllülük ve STK'lar" (\%1), “Gönüllülük ve Kuşaklar" (\%1), "Göçmenler" \%1, “Sosyal Sorumluluk Projeleri” (\%1) ve “Ölçek Geliştirme" \%1 olduğu görülmektedir. Çalışmanın ana konusu olan gönüllü turizm konusunda (\%2) oranında yapılan araştırmaların ise az oluşu dikkati çekmektedir. Ancak rekreasyon ve turizm faaliyetlerinin birbiri ile olan bağlantısı düşünüldüğünde, şu ana değin ağırlıklı olarak "Gönüllülük ve rekreasyon" konulu makalelerin çalışılmış olması sevindiricidir. Diğer yandan, gönüllülüğün esasını oluşturan STK'lar ve Sosyal Sorumluluk Projeleri'nin az çalışılmış olması ise olumsuz bir çıktıdır. Söz konusu konuları içerecek şekilde daha fazla yayımın yapılması, özellikle de gönüllü turizme ilişkin örneklerin artırılması sayesinde gerek gönüllülük faaliyetlerinin gerekse turizme yansımalarının önemi yönünde olumlu katkı sağlanacağı düşünülmektedir.

Araştırmanın bir diğer sonucu ise; makalelerin neredeyse tamamının Türkçe (\%84) yayımlanmış olmasıdır. Bu durum şüphesiz literatürde araştırma yapmak isteyen yerli araştırmacılar ve okuyucular için zengin bir kaynak anlamına gelmektedir. Fakat yabancı araştırmacılar ve okuyucular için de konuya ilişkin bilgi kaynağı oluşturmak oldukça önemlidir. Zira, uluslararası turizm varışları içinde en çok ziyaret edilen ilk on ülkeden biri olan Türkiye'de turizmin çeşitlendirilerek tüm yıla yayılmasının önemi 


\section{5 (1): $1-15$}

düşünüldügünde; gönüllü turizm konusunda yabancı dilde hazırlanacak makalelerin sayı ve nitelik olarak artırılmasının önemi şüphe götürmez bir gerçektir.

Gönüllü turizm, turizmde sürdürülebilirlik ve sorumluluk bilincinin gelişmesinde; yerel halkın turizme katılımında, istihdamın arttırılmasında, az gelişmiş ülkelerde çevre konusunda eğitim ve bilinçlenmenin sağlanmasında, turizmin çeşitlendirilmesi ve rekabet gücünün artırılmasında büyük öneme sahip bir turizm türüdür. Bu turizm türünün Türkiye'de geliştirilmesi, deniz turizminin yanı sıra, diğer kültür ve turizm varlıklarının güçlendirilmesini ve elde edilen gelirlerin bölgesel dağılımını sağlayacaktır. Gönüllü turizm, Türkiye' de henüz gelişimi yavaş olan, bu anlamda farkındalık yaratılması ve sürdürülebilirliğin sağlanması önemli olan bir turizm türüdür. Türkiye' de gönüllülük faaliyetleri üzerine çalışma yapan çok sayıda dernek ve kuruluş bulunmaktadır. Bu dernek ve kuruluşların; ilgili bakanlıklar, üniversiteler ve gençlik kuruluşlarının desteği ile turizm alanında gönüllülük faaliyetleri düzenlemeleri, farkındalığın artırılması açısından önemli olacaktır. Uluslararası gönüllü turizm organizasyonları ile işbirliği içinde geliştirilecek çalışmalar sayesinde ise, Türkiye'ye gönüllü turist olarak gelecek ziyaretçilerin artırılması mümkün olabilecektir. Gönüllü turizm, kültürler arası etkileşimin yoğun olduğu bir turizm türü olması nedeniyle, kültürel mirasın korunması ve sürekliliğinin sağlanması adına gönüllü hizmetlerin geliştirilmesi de başlıca amaçlar arasında yer almaktadır. Tüm bu önerilerin yerine getirilebilmesi açısından, ulusal ve uluslararası örnek çalışmaları içeren gönüllü turizm araştırmalarının sayı ve nitelik olarak artırılması oldukça önemlidir. Zira, yapılan araştırma neticesinde; gönüllü turizm ile ilgili alan yazında da eksikliklerin olduğu tespit edilmiştir. Bu kapsamda gerek lisans, gerek lisansüstü programlarda, öğrencilerin gönüllü turizm konusundaki farkındalığının artırılması amacıyla konuya ilişkin derslerin konması, tez ve araştırma çalışmalarının yapılması da oldukça büyük fayda sağlayacaktır.

Güneş \& Parlak (2020); uluslararası gönüllü projeler kapsamında yapılan faaliyetlerin sürdürülebilir kalkınma hedeflerine doğrudan katkı sağladığını ve bireylerin gönüllü projelere katılımının 2030 sürdürülebilir kalkınma hedeflerinin gerçekleştirilmesinde de önemli bir rolü olduğu belirlemişlerdir. Bu doğrultuda ayrıca, bireylerin günümüzde artan gönüllü yardım etme ve toplumsal fayda sağlama gibi amaçlarının sorumlu turizm anlayışıyla da örtüştügü sonucuna varmışlardır. Dolayısıyla gönüllü turizmin sorumlu turizmle olan ilişkisi, gönüllü turizmin turistler ve yerel halk üzerindeki etkileri, yerel kalkınma ile eğitim ve bilinçlenmeye olan katkıları, potansiyel açıdan öne çıkabilecek bölgeler, Covid-19 küresel salgını esnasında ve sonrasında gönüllü turizmin durumu gibi pek çok konu üzerine çeşitli araştırmaların yapılmasının da önemli olabileceği düşünülmektedir.

Son olarak; konuya ilişkin bu araştırma ULAKBİM tarafından taranan ulusal hakemli dergileri kapsadığından ve bulgulara bu doğrultuda ulaşıldığından; gönüllü turizm bibliyometrik analiz çalışmasının uluslararası alan indeksli, uluslararası hakemli gibi farklı özelliklere sahip dergilerde de yapılması neticesinde daha kapsamlı bir sonuç elde edilebilecektir.

\section{Teşekkür ve Bilgi Notu}

Destek Bilgisi: Bu çalışmanın hazırlanması süresince herhangi bir bireyden ya da kurumdan ayni ya da nakdi bir yardım/destek alınmamıştır.

Etik Onayı: Makalede, ulusal ve uluslararası araştırma ve yayın etiğine uyulduğunu yazarlar beyan eder. Aksi bir durumun tespiti halinde GSI Journals Serie A: Advancements in Tourism Recreation and Sports Sciences Dergisinin hiçbir sorumluluğu olmayıp, tüm sorumluluk makale yazarlarına aittir.

Etik Kurul Onayı: Bu çalışma, TR Dizin etik kurul izni gerektiren çalışma grubunda yer almamaktadır.

Çıkar Çatışması: Makalede herhangi bir çıkar çatışması ya da kazancı yoktur.

Araştırmacıların Katkı Oranı: Çalışma, üç yazarın katkısı ile hazırlanmıştır. Katkı oranları: 1. Yazar = \% 40, 2. Yazar $=\%$ 35, 3. Yazar $=\% 25$ 
Güneş, S.G., Gündoğdu K. \& Aksu, H. S. (2022). Bibliometric Analysis of Volunteer Tourism Articles Published in National Reviewed Journals Indexed by ULAKBIM. GSI Journals Serie A: Advancements in Tourism, Recreation and Sports Sciences (ATRSS), 5 (1): $1-15$

\section{Kaynaklar}

Ar, H. \& Uğuz, S. Ç. (2014). Sürdürülebilir Turizm Çerçevesinde Gönüllü Turizmi ve Permakültür İlişkisi: Permakültür Çiftlik ve Köy Uygulamaları. Proceedings Of VII. Lisansüstü Turizm Öğrencileri Araştırma Kongresi,04-05 Nisan, Kuşadası, Aydın, 222-232

Baillie Smith, M. \& Laurie, N. (2011). International volunteering and development: Global citizenship and neoliberal professionalisation today. Transactions of the Institute of British Geographers, 36(4), 545559.

Bang, H. \& Ross, S. D. (2009). Volunteer Motivation and Satisfaction. Journal of Venue and Event Management, 1(1), 61-77.

Bozok, D., Kılıç, S. N. \& Özdemir, S.S. (2017). Turizm Literatüründe Kırsal Turizmin Bibliyometrik Analizi, Journal of Human Sciences, 14(1), 187-202.

Callanan, M. \& Thomas, S. (2005). Volunteer Tourism: Deconstructing Volunteer Activites Within a Dynamic Environment.İçinde Niche Tourism, (s. 183-200) London: Routledge.

Coghlan, A. \& Fennell, D. (2009). Myth Or Substance: an Examination of Altruism As The Basis of Volunteer Tourism. Annals of Leisure Research, 12(3-4), 377-402.

Demirbulat, Ö.G. \& Dinç, N.T. (2017). Sürdürülebilir Turizm Konulu Lisansüstü Tezlerin Bibliyometrik Profili. Seyahat ve Otel İşletmeciliği Dergisi, 14(2), 20-30.

Ercan, F. (2020). Türkiye'deki Gastronomi Turizmi Konulu Makalelerin Bibliyometrik Analizi. Journal of Tourism and Gastronomy Studies, 8(2), 1058-1075.

Fahimnia, B., Sarkis, J. \& Davarzani, H. (2015). Green supply chain management: A review and bibliometric analysis. International Journal of Production Economics, 162, 101-114.

Güneş, G. \& Dülger, A.S. (2020). Turizm Kavramı, Turizmin Tarihçesi, Turizm İstatistikleri ve Sağllk Turizminin Ülke Ekonomilerine Katkısı. Sağlık Turizmi, Tengilimoğlu, D. (Ed.), içinde Sağlık Turizmi (s. 19-32). Ankara:Siyasal Kitabevi.

Güneş, S.G. \& Parlak, O. (2020). The Role of Voluntary Recreation Activities in the United Nations 2030 Sustainable Development Goals. Journal of Tourism and Gastronomy Studies, 8 (4), 1-15.

Hunter, C. \& Green, H. (1995). Tourism and The Environment, A Sustainable Relationship. London: Routledge.

Karagöz, D. \& Kozak, M. (2014). Anatolia Turizm Araştırmaları Dergisi'nin Bibliyometrik Analizi: Araştırma Konuları ve Kurumlar Arası İş Birliğinin Sosyal Ağ Analizi ile İncelenmesi.Türk Kütüphaneciliği, 28, (1), 47-61

Kesgin, B. (2016). Türkiye'de Gönüllülük Çalışmaları Üzerine Bir Değerlendirme. MSGSÜ Sosyal Bilimler, (13), 119-131.

Koşan, A. \& Güneş, E. (2009). Gönüllülük ve Erzurum 2011 Üniversitelerarası Kış Oyunları. Atatürk Üniversitesi Sosyal Bilimler Enstitüsü Dergisi, 13(2), 1-18.

Kozak, M. A. \& Türktarhan, G. (2012), Gönüllü Turizmine Kavramsal Bir Bakış, Turar Turizm ve Araştırma Dergisi, 1(2), 4-14.

Kurnaz H. A. (2020). Gönüllü Turizm. Güneş, S.G. \& Özdemir S. Akgül, (Ed.), Sorumlu Turizm İçinde (s. 133-152). Ankara: Nobel Akademik Yayıncilık.

Lee, H.Y. \& Zhang, J.J. (2020). Rethinking Sustainability in Volunteer Tourism. Current Issues in Tourism, 23(14), 1820-1832.

Leong, L. Y., Hew, T. S., Tan, G. W. H., Ooi, K. B. \& Lee, V. H. (2020). Tourism research progress-a 
Güneş, S.G., Gündoğdu K. \& Aksu, H. S. (2022). Bibliometric Analysis of Volunteer Tourism Articles Published in National Reviewed Journals Indexed by ULAKBIM. GSI Journals Serie A: Advancements in Tourism, Recreation and Sports Sciences (ATRSS),

$$
5 \text { (1): } 1-15
$$

bibliometric analysis of tourism review publications. Tourism Review, 76(1), 1-26.

Lyons, K. D. \& Wearing, S. (2008). Volunteer Tourism As Alternative Tourism: Journeys Beyond Otherness. Journeys of Discovery in Volunteer Tourism: International Case Study Perspectives, 311.

Nyberg, L., Cater, E. \& Lowman, G. (1996). Ecotourism. A Sustainable Option? Geografiska Annaler. Series B, Human Geography, 78(1), 66. https://doi.org/10.2307/490974

Özkul, E. \& Birinci, M. C. (2018). Gönüllü Turizm: Turizmde Güncel Konu ve Eğilimler. Aydın, Ş. \& Boz, M. (Ed.) S:343-358, Ankara: Detay Yayıncilık.

Palabıyık, H. (2011). Gönüllülük ve Yerel Hizmetlere Gönüllü Katılım Üzerine Açıklamalar. Yönetim Bilimleri Dergisi, 9 (1), 82-114.

Palacios, C. M. (2010). Volunteer Tourism, Development and Education in a Postcolonial World: Conceiving Global Connections Beyond Aid. Journal of Sustainable Tourism, 18(7), 861-878.

Polat, Z. A. Saraçoğlu, A. \& Duman, H. (2019). Harita Dergisi'nin Bibliyometrik Analizi. Harita Dergisi, 161, 46-56.

Romero, M. E. P., Flores-Romero, M. B., Alfaro-García, V. G., \& Merigó, J. M. (2021). Tourism competitiveness: bibliometric analysis of global scientific production from 1991 to 2018. Inquietud Empresarial, 21(1), 55-73.

Scheyvens, R. (2002). Backpacker Tourism and Third World Development. Annals of Tourism Research, 29(1), 144-164.

Sin, H. L. (2009). Volunteer tourism - “involve me and I will learn”?. Annals of tourism research, 36(3), 480-501.

Stoddart, H. \& Rogerson, C. M. (2004). Volunteer Tourism: The Case of Habitat for Humanity South Africa. Geojournal, 60(3), 311-318.

Şahin, S. \& Acun, A. (2015). Turist Rehberliği Alanının Bibliyometrik Profili (Ulusal Turizm Kongreleri Bildirileri), Balıkesir Üniversitesi Sosyal Bilimler Enstitüsü Dergisi, 18(34), 213-234.

Tarınç. A. (2020). Gönüllü Turizm (Dijital Baskı). Erişim Adresi: https://iksadyayinevi.com

Tomazos, K. \& Butler, R. (2009). Volunteer Tourism: The New Ecotourism?. Anatolia, 20(1), 196-211.

Tosun, C. (2001). Challenges of Sustainable Tourism Development in the Developing World: The Case Of Turkey. Tourism management, 22(3), 289-303.

Ulu, S. \& Akdağ, M. (2015). Yayınlanan Hakem Denetimli Makalelerin Bibliyometrik Profili: Selçuk Dergisi Örneği. Selçuk İletişim, 9(1), 5-21.

Wall, G. (1997). Forum: Is Ecotourism Sustainable? Environmental Management, 21(4), $483-$

491. https://doi.org/10.1007/s002679900044

Wilkinson, B., Mccool, J. \& Bois, G. (2014). Voluntourism: an Analysis of The Online Marketing of a FastGrowing Industry. International Journal of Communication And Health, 4, 10-15.

Yilmaz, I. (2019). Bibliometric analysis of bibliometric studies on tourism published in Turkey. Anais Brasileiros de Estudos Turísticos-ABET, 9(1, 2 e 3).

Zahra, A. \& Mcintosh, A. J. (2007). Volunteer Tourism: Evidence of Cathartic Tourist Experiences. Tourism Recreation Research, 32(1), 115-119. 